\title{
Democracy in Latin America: status and prospects
}

\author{
Democracia en América Latina: estatus y perspectivas
}

\author{
John A. Booth / johnbooth@unt.edu \\ University of North Texas, USA \\ Leticia Heras-Gómez / herasleticia@yahoo.com.mx \\ Universidad Autónoma del Estado de México, México
}

\begin{abstract}
The purpose of this essay is to examine the status of democracy in Latin American countries as well as the prospects upcoming for the region in the present decade. We will provide a map of the subject that includes a basic definition of democracy, an overview of theories about how democracies arise and may be maintained, as a continuum, and a review of what we know empirically about Latin American democratization. We suggest a model in which political culture and social structure influence each other, and that both directly influence political processes, which in turn mediates between these causal factors and the actual emergence of democratic rules of the political game in every particular country. The approach is completed with a series of LAPOP Data that shows up how far and in what direction democracy is taking place in Latin America.
\end{abstract}

Key words: democracy, political culture, social structure, Latin America.

Resumen: El propósito de este ensayo es examinar el estatus democrático de los países latinoamericanos, así como las perspectivas de avance de la democracia en la región para la presente década. Ofrecemos un mapa del objeto de estudio que incluye una definición básica de democracia, un panorama de las teorías acerca del desarrollo de la democracia y como ésta puede ser mantenida, como un continuum, y una revisión de lo que conocemos empíricamente sobre la democratización latinoamericana. Sugerimos un modelo en el cual la cultura política y la estructura social influyen una sobre otra, y ambas influyen directamente los procesos políticos, los cuales a su vez median entre éstos y el surgimiento real de reglas democráticas en el juego político en cada nación latinoamericana en particular. El estudio se completa con los datos de LAPOP que intentan mostrar hasta dónde y en qué dirección se instala la democracia en la región latinoamericana.

Palabras clave: democracia, cultura política, estructura social, América Latina. 


\section{Introduction}

The democratization of Latin America and the status of democracy in the region are topics of great interest. In the 1970s, constitutional electoral democracy as a system of government was the exception in Latin America rather than the rule. Most political systems had written constitutions that embraced the liberal democratic principles, but many of them failed to live up to their own legal norms and principles. Undemocratic elites controlled a majority of the region's polities, in some cases overtly ignoring legality and governing defacto. In others, elites paid lip service to constitutional democracy by enacting parodies of its forms and processes while undermining it with subterfuges that denied citizens a meaningful political role. The handmaid of both models -overt authoritarianism and democratic charade- was the widespread violation of human rights, employed by rulers to discourage meaningful citizen participation in rule.

So much has changed in Latin American politics over the four decades since 1970. In most of the region today constitutional, electoral democracy is in practice. Since the early 2000s average Latin American citizens have enjoyed far more say in who governs and represents them than at any previous time in the region's history. Despite setbacks and wobbles and a very few exceptions to this new pattern, democracy as a system of government appears well established as the main organizing system for government throughout the Americas.

Despite this institutional and practical progress, constitutional electoral democracy as it is practiced in Latin America today has many well-known flaws. The critiques of William Robinson, Peter Smith, for example, highlight the limitations in effective citizen input into the systems and of their public policy outputs (Robinson, 1996, 2003; Smith, 2005). Robinson, for example, labels Latin America's governing systems "polyarchies" rather than democracies in order to highlight their limitations both in true citizen influence and in the benefits they generate for their citizens. Cognizant of the merits of such criticisms, it is still worth the effort to conduct an evaluation of the status of democracy in Latin America and the Caribbean. At a minimum one must argue that not even the harshest critics of the region's democracies (or polyarchies if you wish) can deny that democratic regimes are less repressive than their autocratic predecessors. In effect democracies in the Americas kill and repress many fewer of their citizens than did the undemocratic governments that came before them. 
In the pages that follow we will provide a map of the subject that includes a basic definition of democracy, an overview of theories about how democracies arise and may be maintained, and a review of what we know empirically about Latin American democratization.

\section{Democracy defined}

The term democracy comes to us from the ancient Greeks, where rule (kratein) by the people (demos) was practiced in several Hellenic city states. ${ }^{1}$ Aristotle described the characteristics of democracy as involving rule by the free and poor majority (of males) (Aristotle, 1962). Aristotle regarded democracy as a deficient form of government because of its tendency to abuse minorities, to be unstable, and to succumb to the wiles of demagogues. He argued that democratic polities were better if they adopted constitutions to define institutions, protect minorities from abuse by majorities and to provide for stability. By today's inclusive standards of citizenship and human rights, the Athenian practices of slavery and exclusion of women from citizenship constituted additional flaws in democracy that have been abolished in modern democratic polities. Despite the ancient roots of these central features of democracy, and despite their initial limits on citizenship, these defining traits identified by Aristotle constitute the essence of modern democratic governance. Democracy refers to participation in rule by the majority of citizens, tempered by a constitution to protect minorities' rights and promote stability.

Hellenic democratic governance eventually collapsed. Functioning democracy at the level of the nation state did not begin to develop for two millennia. Some European city states of the late Middle Ages and early Renaissance adopted proto-democratic features, but it was not until the American and French Revolutions of the late eighteenth century that modern democracy began to take shape. Challenging absolutist monarchism, Liberal theorists and social contract thinkers (including Hobbes, Locke, Jefferson and Rousseau) laid the foundations for the principles of equality before the law and popular sovereignty that undergird modern democratic theory and democratic political systems alike. Later, critics of capitalism and Liberalism on the left offered critiques that shaped efforts to promote greater economic

1 Democracy or polities with democratic features may well have existed before Greek antiquity in prehistoric societies, but there is little or no record of it; for examples see Midlarsky (Midlarsky, 1997). 
equality in democracies (Cohen, 1973; Dahl, 1998; Held, 2001; Pateman, 1970). Liberal constitutional proto-democracies appeared in the United States and Europe and Latin America in the late eighteenth and throughout the nineteenth centuries. Typically elites dominated these systems and the rules of the game excluded large parts of their populations from suffrage. Using inclusive citizenship as a criterion of democracy (i.e., that no major segments of the population be excluded from citizenship and suffrage), truly democratic nation states did not arise until the late nineteenth and more commonly the twentieth century (Doorenspleet, 2005, 2000; Huntington, 1991).

\section{Conditions for democracy's development}

\section{Transition to Democracy}

What do scholars believe accounts for democratization, and how might their arguments relate to or explain the Latin American cases? Theoretical explanations about the development of democracy breaks down into three basic types of arguments - cultural, structural, and process- related theories.

The first of these is cultural theories, which essentially posit that the attitudes and values of citizens determine the rules of the national political game. Two influential examples illustrate the approach. Seymour Martin Lipset, in two seminal articles and his book Political Man (Lipset, 1959a, $1961,1959 \mathrm{~b})$ argued that the relative poverty of developing nations, among which he included Latin American states, gave these nations large proportions of poor citizens who were more prone to be authoritarian than middle class and upper class citizens. ${ }^{2}$ Lipset believed that the presence of many citizens with authoritarian norms made it harder for poor countries to become democracies. Lipset conducted some of his research on working class authoritarianism in Argentina. Gabriel Almond and Sidney Verba made another famous cultural argument in their classic The Civic Culture (Almond and Verba, 1963). They compared public opinion data from Mexico, Italy, the United States, Britain and Germany. They argued that democracy lagged in Mexico and Italy because of an excess of "subject oriented" citizens and

2 A major influence on Lipset was the work of Teodor Adorno et al. (Adorno, E. FrenkelyBrunswik and Sanford, 1950), who posited the working class authoritarianism explanation to account for the rise of totalitarian regimes in Europe in the 1930s. 
a lack of sufficient "participant oriented" citizens. Other scholars have more recently made similar arguments for the primacy of culture in the construction of democracies. They include Ronald Inglehart (Inglehart, 1990, 1988; Inglehart and Welzel, 2005) and Robert Putnam (Putnam, 2000, 1993). And using this approach other authors tried to find out cultural inheritance in the shape of political values, such as Heras (2004) or about the influence of political system type in political culture values (Booth and Seligson, 1984).

Such cultural arguments have elicited several critiques. One is that cultural theories ignore fundamental social and political structures, especially the powerful role of political elites. This view argues that mass publics, their norms and numbers notwithstanding (Linz and Stepan, 1978) political power to determine the rules of national politics in regime change. Thus, considering that democracy is about mass publics governing themselves, it is ironic that mass publics do not themselves actually establish democratic regime-elites. Elite attitudes and behavior determine both the formation and deformation or dissolution of democracies (Linz and Stepan, 1978; Peeler, 1998, 1992; Przeworski, 1986). Thus mass attitudes may matter little for democratization. There is empirical evidence, however, that low mass public support for democracy or high dissatisfaction with regime performance may trigger antidemocratic behavior by elites (Booth and Seligson, 2009; Perez, Booth and Seligson, 2010; Seligson and Booth, 2009).

The second critique of the cultural theories of democratization comes from empirical analysis of the direction of causality between cultural norms and regime type. Both Muller and Seligson (1994) and Jackman and Miller $(2004,1996)$ bring multi-level data on individual norms and system traits to bear on this problem of the direction of influence -i.e., whether mass political culture shapes system rules or system rules shape culture-. They demonstrate that system-level rules of the political game exercise stronger influences on mass culture than vice versa. In essence, citizens living in autocracies adopt authoritarian cultural norms, and when the rules change to democracy public norms follow as an adaptive mechanism. The findings of both teams undermine arguments for the cultural determination of democracy.

If not culture, then, what does cause democratization? We are left with social structure, and political processes and elites. Structural theories of democratization range widely, but share a common idea that large-scale features of social systems determine the onset of democracy. Most structural theories emphasize how shifts in the distribution of critical material and organizational resources among political actors can lead to democracy. 
Democratic regimes emerge when the level and distribution of political and economic resources (Gasiorowski, 2000; Lipset, 1994, 1959b; Muller, 1997; Vanhanen, 1997) and the mobilization of resources by organized middle or working classes (Rueschemeyer, Stephens and Stephens, 1992) permit formerly excluded actors to disrupt the extant authoritarian coalition. Elites are more likely to allow democratization when they enjoy capital mobility rather than capital rigidity (such as having wealth based on large landholdings) (Boix, 2003; Boix and Stokes, 2003; Muller, 1997). Links between democracy and economic development levels are debated. Przeworski et al. however, argue based on their empirical analysis, that the development of democracy is not correlated to economic development levels. Nevertheless, their analysis shows that democracy's survival does depend on a certain level of prosperity (Przeworski et al., 2000).

In contrast to the inward looking arguments about national economic features and class development, a different structural argument looks outside the democratizing country. Typically citing the cases of postwar Germany and Japan, this theory holds that democracy may be imposed upon a country by external actors (Whitehead, 1991). Empirical investigation of dozens of cases of imposed democracy reveals a fairly high rate of failure (Enterline and Greig, 2005, 2008).

Another approach to democratization focuses on political and economic elites. Key societal leaders and power holders must engineer specific democratic arrangements (elite settlements) and agree to operate by them. The broader the coalition of political forces involved, the more stable and consolidated a democratic regime will be. Weak elite commitment to constitutional democratic norms can undermine a democratic regime as opportunistic elites act undemocratically to seek their narrow advantage (Higley and Burton, 1989; Higley and Gunther, 1992; Huntington, 1991; Karl, 1992; Peeler, 1992, 1985). Robinson's explanation of the emergence of minimalist formal electoral democracy includes both structural arguments (global economic and political forces and institutions impinge on the local) and elite arguments (international and global elites cooperate to impose democratic rules of the game on local elites) (Robinson, 1996, 2003).

A final approach can be labeled process theory, which examines not the causes of democratization, but its mechanics. These scholars, some already mentioned in the elite approach, often focus on the pacts that must be made to bring about a democratic transition, agreements among powerful political actors on the terms of the new political game (Boix, 2003; Higley and Gunther, 1992; Huntington, 1991; O’Donnell, Schmitter and Whitehead, 
1986; Rustow, 1970; Stepan, 1986). Who must be involved in regime change, under what terms they will participate, starting points and paths forward all constitute topics for process theories of democratization.

Political systems are very complex and the political relations among elites and between elites and masses are unlikely to be explained simply. Indeed, this is causal complexity suggested by the fact that various students of democracy cited draw upon more than one explanatory factor to account for the transition to democracy-some combination of culture, structure, and process-. Lipset, for example, emphasizes both social structure and economic development as causes of democratization (Lipset, 1961). Robinson views local and national elites as agents promoting democratization on behalf of the global capitalist economic development process (Robinson, 1996). Barrington Moore focuses on social structures such as relations between social classes, land tenure systems, and the behavior and resources of certain elites and non-elites that may lead to the emergence of democracy (Moore Jr., 1966). Mahoney makes similar arguments about the democratization of Central America (Mahoney, 2001). Higley and Burton's elite theory of democratic settlements includes both processes and paths to elite pacts as well as the political culture of the elites who must establish the new democracies (Higley and Burton, 2006). Huntington ranges widely, embracing both elite cultural arguments and process theories (Huntington, 1991). Thus I suspect that several or even all of these factors are involved, likely in various combinations case by case, in the democratization of Latin America.

Figure $1^{3}$ shows a theoretical model that suggests possible interrelationships among the theoretical explanations for democratization. The solid blue arrows indicate likely causal influences from one factor toward each other factor and toward democracy (see figure 1).

What Figure 1 and the empirical literature about democratization (see below) suggest is that political culture and social structure influence each other, and that both directly influence political processes, which in turn mediates between these causal factors and the actual emergence of democratic rules of the political game in a particular country. That solves the obvious problem that social classes or the values of individuals cannot actually fashion a democratic regime. Rather, elites put together political processes that establish democracies when they elect to do so or are forced to do so by public opinion/culture and by structural pressures. Culture and structure may directly influence democratization, but that seems less likely

3 All the figures and the table are in the Annex, at the end of this article. 
than an elite-mediated process. There are also likely feedback channels in the model, by which the existence of democracy alters both political culture and social structures. Such feedback systems may be very important to democratic consolidation.

Acquiring democracy is one thing and as it is now manifest, the theories about it are complex; sustaining democracy once it exists - democratic consolidation- is yet another. This is the topic to which we now turn.

\section{Consolidation of democracy}

Consolidation of democracy refers to keep democracy going once it is established, and to deepen the commitment of players in the democratic political game to the game's maintenance (Diamond, 1999; Przeworski, 1986; Rustow, 1970). Theories of democratic consolidation may be categorized similarly to those of the transition to democracy, according to whether they focus on political culture, social structure and political institutions, or political processes.

The most prominent structural argument for democratic consolidation is that once a country reaches a certain level of economic development it is much more likely to become and remain a democracy. Empirical research indicated that there was an economic threshold for stable democracy (Lipset, 1961; Seligson, 1987). The most prominent work in this regard is by Przeworski et al., who contend that economic development does not matter for the transition to democracy, but that it matters for democracy's survival. Once democratic regimes attain a certain level of economic development, empirical evidence suggests that they do not break down or lose their democratic status.

Another approach to consolidation is a process theory based on elites and their role in keeping democracy. This argument is that the broader the coalition that forges an elite settlement on democracy, the more likely it is to be stable and long lasting (Higley and Burton, 2006; Higley and Burton, 1989; Higley and Gunther, 1992). The explanation for this is that in a regime in which most national political and economic elites agree on democratic rules of the game, the less likely it is that dissatisfied counter-elites will challenge the regime, and the more likely that the regime will survive if challenged (Peeler, 1998, 1992; Przeworski, 1986).

Cultural arguments about democratic consolidation usually affirm that large proportions of mass publics need to prefer democratic governance 
or embrace a democratic regime (Diamond, 1999; Lipset, 1959a; Norris, 1999; Rose, Mishler and Haerpfer, 1998). Robert Putnam argues that social capital, a combination of interconnectedness in groups and networks (civil society) and of interpersonal trust and other democracy-supporting norms, is essential to keep democracy. He has examined the apparent decline of social capital in the United States and expressed fear that it is eroding as faceto-face interactions among Americans have declined in the late twentieth century (Putnam, 2000, 1995). Seligson has linked the decline of trust in political institutions in recent decades to the erosion of voter turnout in Costa Rica, the oldest continuous democracy in Latin America (Seligson, 2002).

Some cultural theories of consolidation or democratic survival are more complex. One argues that particular combinations of critical attitudes among mass publics are essential to democracy's survival. For example, working on the assumption that mass values constrain political system elites, Seligson and others have argued that two attitudes matter - political tolerance and support for institutions-. ${ }^{4}$ They contend that the greater the fraction of a country's population that affirms positive support for both at the same time, the greater the likelihood that democracy will survive (Booth, 2010; Córdova and Cruz, 2007; Perez and Seligson, 2008; Seligson et al., 2006). Other configurations are likely to tend toward unstable democracy, unstable authoritarianism, or stable authoritarianism. Booth and Seligson choose a somewhat different configuration of attitudes. They argue that when the number and ratio of citizens who support democracy, positively evaluate institutions, and approve of the government's economic performance are greater, system stability will be enhanced (Booth and Seligson, 2009).

These are some of the major theories about democratization and the consolidation of democracy. Because both democratization and the maintenance of democratic systems are quite complex social processes, it appears unlikely that any single or simple explanation would be sufficient to account for all cases.

The remainder of this paper turns to an assessment of the status of democratization and democratic consolidation in Latin America.

It is worth to add that we embraced the notion of a scalar view of democracy, rather than a binary or dichotomy notion of democracy

4 See, for example, works by Seligson and his collaborators, including Booth, Córdova and Cruz, and Pérez and Seligson (Booth, 2010; Córdova and Cruz, 2007; Perez and Seligson, 2008; Seligson et al., 2006). 
(Bernhagen, 2009), meaning that democratization is a continuum from a certain point of departure, which would be an authoritarian regime, to a certain political threshold which would be a consolidated democracy. We also sustain with some scholars (Dahl, 1989; Hyland, 1995) that as a scalar concept "...would enable us to place any political system on a scale of more or less democracy" (Hyland, 1995; in Bernhagen, 2009: 27). Our study pays attention to this sort of measuring continuum of democracy in Latin America, because it would be very difficult to consider some countries as full or consolidated democracies and some as non-democracies, as the reader could grasp in the next pages.

\section{An overview of Latin America's democratization}

Latin America had several brief instances of political inclusion of mass publics in independence movements and the founding elections of newly independent states. But after those episodes Latin American nations quickly fell under the control of landed elites who excluded mass publics from politics for extended periods. A handful of proto-democracies with narrowly based election systems arose in Latin America in the late nineteenth and early twentieth centuries (e.g., Argentina, Chile, Costa Rica) but even the most successful of those limited electoral democracies experienced reversals and breakdowns and episodes of military intervention in politics (Booth, 1998; Gil, 1966; Molina, 2005; Nohlen, 1992, 2005, 1993; Peeler, 1985; Schneider, 2007; Smith, 1974). True constitutional, electoral democracies did not become successfully established in Latin America until after World War II; most of them have appeared only since the 1970s (Marshall and Jaggers, 2008; Martz, 1967; Peeler, 1998; Schneider, 2007; Smith, 2005). Figure 2 graphs the number of democracies, autocracies and anocracies in the Americas (excluding the United States and Canada) at 10-year intervals from 1946 to $2008^{5}$ (see Figure 2).

As it is seen (Figure 2) Polity IV classifies only 2 regimes in the region as democracies in 1946, and 5 as autocracies, with 13 anocracies (regimes

5 These designations of regime types are those used by the Polity IV Project to characterize governments (Marshall and Jaggers, 2008). Polity IV employs a 21 point scale ranging in one point intervals from -10 (completely autocratic) to +10 (completely democratic). Any system with a score of -6 to -10 is classified as an autocracy; any system with a score of +6 to +10 is classified as a democracy. Those systems in between (from -5 to +5 ) are classified as anocracies, and possess some characteristics of both. 
somewhere in between autocracy and democracy). Some interesting things transpire after that. The number of anocracies declines fairly steadily until about 1985, after which it varies from 1 to 4 . The number of autocratic regimes increases until 1975, demonstrating that several governments became less democratic in the three decades following World War II. After then, however, the number of autocracies falls from ten in 1975 to only one by 1995 , and remains at that level (the autocracy persisting, of course, is Cuba). The small number of democracies rises to 7 by 1965, declines to 6 in 1975 , but then takes off and doubling by 1985 . The most democracies observed are 21 (of the 25 nations included at these decade intervals) and is recorded in 2005.

To employ Huntington's phrase, Latin America clearly participated in a wave of democratization (Huntington 1991) that had two phases, a tentative one in the 1960s followed by reversals or democratic breakdowns, and then a much stronger democratization wave in the 1980s and 1990s. ${ }^{6}$ A grand question at present is whether the reversals observed in the last few years constitute a reverse wave of democratic breakdown. To put it otherwise, have Latin America's electoral democracies consolidated? The Venezuelan case continues to trouble observers. Its increased restrictions on rights and liberties and the removal of many constitutional restraints on the executive caused Venezuela to be downgraded by Polity IV in 2007 to an anocracy. Another questionable case is Ecuador, which Polity IV also downgraded to an anocracy in 2007 (Marshall and Jaggers, 2008); yet another country, not accounted for in figure 1 is, Honduras, which in June 2009 had a coup d'état. A de facto civilian government ruled the country until a new government was elected and inaugurated following the regularly scheduled December 2009 elections.

The large number of transformations to democracy of Latin America, from the 1970s until Mexico's full emergence as a new member of the club in 2000, is a remarkable historical process. It invites an obvious question of why so many countries moved in the same political direction within such a

6 Huntington placed these developments in his third wave of democratization. Doorenspleet (2000) recalculated the wave phenomenon using a tougher criterion for identifying democracies (Huntington employed 50\% male suffrage to qualify for democracy, while Doorenspleet insisted on broadly inclusive citizenship and suffrage and more careful attention to the number of countries in the world). Doorenspleet's data essentially make Huntington's first wave disappear, and thus locates Latin American democratization in a second wave. 
short time span. For some ideas about what might have happened it is useful to consider democratization theories.

\section{Empirical evidence about democratization in Latin America}

The next part attempts to provide empirical evidence and data about democratization and democratic consolidation in Latin America. Regarding cultural values, empirical evidence is not strong for the whole region. There are few approaches like Booth and Seligson (1984, 1994) who found support for democracy in Mexico and Nicaragua in pre-democratic stages. Nonetheless evidence about processes (elite pact and waves of democracy) is more abundant. We have well known study cases such as Colombia 1958, Venezuela 1959, El Salvador 1992, Guatemala 1996 (Huntington, 1991; Peeler, 1998; Karl, 1992), based on pact elites negotiation that renders stability. Waves of democracy can be seen graphically in Figure 3.

There was clearly a major wave from mid eighties up to the first decade of the new century (see also Smith, 2005), and a minor wave in the mid fifties up to the mid sixties.

Regarding social structure, we found out evidences in both sides. First, there is a positive relationship between economic development and mobilization of working and middle classes and democracy, at least they are associated with democratization (Rueschemeyer et al., 1992). Also for all developing countries (global sample) the per capita GDP is positively related with democratization (Epstein et al., 2006), who contradicts Przeworski et al. (2000).

At the same time, there is limited direct relation, between economic development as a whole in Latin America, but a positive one between industrialization and literacy and democratization. We can also observe a positive relation between broader distribution of power resources and democratization in Latin America and globally (Vanhanen, 1997).

Concerning democratic consolidation, theories based on culture show that high levels of democratic values tend to support democratic practices, as it can be seen through some new evidence from LAPOP 2010 (study of 40000 respondents across the Americas).

With regard to processes, in terms of democratic consolidation, many case studies and histories of elite pacts in Latin America can be found. Additionally, looking at aggregate data, we can observe in Figure 4 that people all over America reveal support for democracy with above 50\%, and 
none of them show less than $60 \%$. However, in 11 out of 25 countries this support declined in only two years from 2008 to 2010 (see Figure 4).

We can also observe that tolerance to criticisms against the system performs levels between $43 \%$ (Haiti) up to $66.7 \%$ (Costa Rica) and more importantly, most countries are getting closer to 50\%, including Bolivia, Honduras, Peru and Dominican Republic, which are just adjusting their political system to democratic practices; and in the case of Mexico (49.2\%) it can be seen as the result of a long lasting authoritarian regime; Figure 5 shows these data.

However, the number of citizens who support democratic institutions remains lower than tolerance to the system criticisms. The percentage comes from $44 \%$ (Trinity and Tobago) up to only 68\% (Uruguay). ${ }^{7}$ Most countries are located from forties to sixties. This may be considered a gradual confidence in institutions on behalf of the citizenry. Figure 6 shows data per country (see Figure 6).

Another feature to consider is the combination of tolerance to critics and support for the system (support for institutions). What can be seen is a general upward tendency towards tolerance and an initial disposition to support institutions. Critical cases in Latin America are Paraguay, Peru, Ecuador, Guatemala, Bolivia, which can be an evidence of very early stages of tolerance and support for institutions (see Figure 7).

One last measure of democratic consolidation is the "Level of Triple Satisfaction", which is the combination index calculated on the basis of being above or below the midpoint of institutions support, support of democratic principles and evaluation of government's economic performance $(0=$ dissatisfied with all, 50=Mixed, $100=$ satisfied with all). By 2010, this index surpassed 50\% in most Latin American countries; only Guatemala, Peru, Belize and Jamaica persisted behind this line. This triple satisfaction index could picture that in Latin America, at least by 2000, people were expecting a better performance from the democratic regime, not just electoral features, but also a better economic performance (see Figure 8).

It may be an optimistic view, but according to these data, democracy is slowly but consistently becoming solid in Latin America. Prospects for democracy will be examined in the next part.

7 The case of Haiti can be considered as a very particular performance towards democracy, being one of the last countries to embrace pro-democratic institutions and practices. 


\section{Prospects for democracy in Latin America}

Some considerations must be done to the threats and challenges of Latin American democracy. First of all the deterioration of restrictions on the executive power have to be taken into account (Venezuela, Bolivia, Ecuador, Nicaragua); truly undemocratic events such as the coup in Honduras in 2009; police uprising in Ecuador, and "the pact" in Nicaragua FSLN-PLC. In addition, we have to consider the erosion of democracy scores in Latin America, as well as the possibility of a backward wave, and finally the sharp economic downturn of 2008-2009 in a possible negative impact on democratic values (see Figure 9).

Also recent trends in the index of the "triple satisfaction" 2008-2010, shows that 14 of 22 cases increased, and it moved down in 5-Belize, Mexico, Argentina, Dominican Republic and Colombia - and that it is very low in Ecuador, Honduras, Jamaica, Peru, and Guatemala; (see Table 1). This table confirms that there is not a general trend about satisfaction with democracy as a whole (institutional, economic performance and a normative system) in Latin America, and that two years of negative performance can have an impact in the prospects for democracy (see Figure 10).

\section{Conclusions}

This approach to the status and prospects to democracy in Latin America enables us to develop Table 1 .

We see countries such as Venezuela, Ecuador, Nicaragua and, of course, Honduras still struggling with institutional problems; countries with persistent low levels of democratic values, such as Guatemala, Paraguay and Jamaica; and finally countries with an erosion of democratic values (dynamics) such as Mexico, Argentina and Belize. Good news is that no country appears in the 3 lists, which allows us to confirm that most Latin American countries do not portray major problems; even though some countries are still carrying on with difficulties.

To conclude it can be said that theories of democratization and consolidation are showing certain progress. We can also conclude that empirical evidence about Latin America is achieving major levels, but this evidence varies by subject, and so are the prospects for democracy which are by and large mixed. 
John A. Booth and Leticia Heras-Gómez. Democracy in Latin America: status and prospects

The configurations of attitudes which maintain democracy in some countries had set backs, as well as elites are threatening institutions in some countries. However, democratic values are generally strong and have withstood the economic shock.

\section{Bibliography}

Adorno, T. W. et al. (1959), The Authoritarian Personality, New York: Harper and Row.

Almond, Gabriel A. and Sidney Verba (1963), The Civic Culture: Political Attitudes and Democracy in Five Nations, Princeton: Princeton University Press.

Aristotle (1962), Politics (Aristotle's Politics), Oxford: Clarendon Press.

Bernhagen, P. et al. (2009), Democratization, Oxford: Oxford University Press.

Boix, Carles (2003), Democracy and Redistribution, Cambridge: Cambridge University Press.

Boix, Carles and Susan C. Stokes (2003), "Endogenous Democratization", in World Politics, vol. 55, no. 4, New Jersey: Princeton Institute for International and Regional Studies.

Booth, John A. (1998), Costa Rica: Quest for Democracy, Boulder: Westview Press.

Booth, John A. (2010), Cultura politica de la democracia en Nicaragua, 2010: Consolidación Democrática en las Américas en tiempos difíciles, Nashville, TN: Vanderbilt University.

Booth, John A. and Mitchell A. Seligson (2009), The Legitimacy Puzzle in Latin America: Democracy and Political Support in Eight Nations, Cambridge: Cambridge University Press.

Booth, John A. and Mitchell A. Seligson (1984), "The Political Culture of Authoritarianism in México: a Reaxamination", in Latinoamerican Reseach Review, vol. XIX, no. 1, Pittsburgh: University of Pittsburgh Press.

Cohen, Carl (1973), Democracy, New York: The Free Press.

Córdova, Ricardo and José M. Cruz (2007), Cultura Politica de la Democracia en el Salvador: 2006, San Salvador: Instituto Universitario de Opinión Pública (IUDOp-UCA).

Dahl, Robert A. (1998), On Democracy, New Haven: Yale University Press.

Diamond, Larry (1999), Developing Democracy: Toward Consolidation, Baltimore: Johns Hopkins University Press.

Doorenspleet, Renske (2005), Democratic Transitions: Exploring the Structural Sources of the Fourth Wave, Boulder: Westview Press.

Doorenspleet, Renske (2000), "Reassessing the Three Waves of Democratization", in World Politics, vol. 52, no. 3, New Jersey: Princeton Institute for International and Regional Studies.

Enterline, Andrew J. and J. Michael Greig (2005), "Beacons of Hope? The Impact of Imposed Democracy on Regional Peace, Democracy and Prosperity", in Journal of Politics, vol. 67, no. 4, Chicago: University of Chicago Press. 
Enterline, Andrew J. and J. Michael Greig (2008), “The History of Imposed Democracy and the Future of Iraq and Afghanistan", in Foreign Policy Analysis, no. 4, Missouri: International Studies Association, University of Missouri.

Epstein, D. L. et al. (2006), "Democratic transitions", in American Journal of Political Science, no. 50, Michigan: Michigan State University.

Gasiorowski, Mark J. (2000), "Democracy and Macroeconomic Performance in Underdeveloped Countries: An Empirical Analysis", in Comparative Political Studies, vol. 33, no. 3, Minnesota: Sage Publications, University of Minnesota.

Gil, Federico G. (1966), The Political System of Chile, Boston: Houghton Mifflin.

Held, David (2001), "Democracy", in The Oxford Companion to Politics of the World, Oxford: Oxford University Press.

Heras, L. (2004), "Cultura Política y Democratización en América Latina", in Revista de Ciencias Sociales, vol. 103-1, no. 2, Costa Rica: Universidad de Costa Rica.

Higley, John and Michael Burton (2006), Elite Foundations of Liberal Democracy, Lanham, Maryland: Rowman and Littlefield.

Higley, John and Michael G. Burton (1989), "The Elite Variable in Democratic Transitions and Breakdowns", in American Sociological Review, no. 54, Michigan: Interuniversity Consortium for Political and Social Research, University of Michigan.

Higley, John and Richard Gunther (1992), Elites and Democratic Consolidation in Latin America and Southern Europe, Cambridge, New York: Cambridge University Press.

Huntington, Samuel (1991), The Third Wave: Democratization in the Late Twentieth Century, Norman: University of Oklahoma Press.

Inglehart, Ronald (1990), Culture Shift in Advanced Industrial Society, Princeton: Princeton University Press.

Inglehart, Ronald (1988), "The Renaissance of Political Culture", in American Political Science Review, vol. 82, no. 4, Texas: Department of Political Science, University of North Texas.

Inglehart, Ronald and Christian Welzel (2005), Modernization, Cultural Change and Democracy, New York: Cambridge University Press.

Jackman, Robert W. and Ross Alan Miller (2004), Before Norms: Institutions and Civic Culture, Ann Arbor: University of Michigan Press.

Jackman, Robert W. and Ross Allen Miller (1996), "The Poverty of Political Culture", in American Journal of Political Science, no. 40, Michigan: Department of Political Science and the School of Social Sciences, Michigan State University.

Karl, Terry Lynn (1992), "El Salvador's Negotiated Revolution", in Foreign Affairs, vol. 71, no. 2, New York: Council of Foreign Relations.

Linz, Juan and Alfred Stepan (1978), The Breakdown of Democratic Regimes, Baltimore: John Hopkins University Press.

Lipset, Seymour Martin (1959a), "Democracy and Working-Class Authoritarianism", in American Sociological Review, no. 24, Michigan: Interuniversity Consortium for Political and Social Research, University of Michigan. 
Lipset, Seymour Martin (1961), Political Man: The Social Bases of Politics, Baltimore, MD: Johns Hopkins University Press.

Lipset, Seymour Martin (1994), “The Social Requisites of Democracy Revisited”, in American Sociological Review, no. 59, Michigan: Interuniversity Consortium for Political and Social Research, University of Michigan.

Lipset, Seymour Martin (1959b), "Some Social Requisites of Democracy: Economic Development and Political Legitimacy", in American Political Science Review, no. 53, Texas: Department of Political Science, University of North Texas.

Mahoney, James (2001), The Legacies of Liberalism: Path Dependence and Political Regimes in Central America, Baltimore: Johns Hopkins University Press.

Marshall, Monty and Keith Jaggers (2008), Polity IV Country Reports 2008, Vienna Virginia, EUA: Center for Systemic Peace.

Martz, John D. (1967), “Costa Rican Electoral Trends, 1953-1966”, in The Western Political Quarterly, vol. 20, no. 4, Utah: Sage Publications, University of Utah.

Midlarsky, Manus I. (1997), Inequality, Democracy and Economic Development, Cambridge: Cambridge University Press.

Molina Jiménez, Iván (2005), Demoperfectocracia: La Democracia Pre-Reformada en Costa Rica (1985-1948), Heredia, Costa Rica: Universidad Nacional.

Moore Jr., Barrington (1966), Social Origins of Dictatorships and Democracy: Lord and Peasant in the Making of the Modern World, Boston, MA: Beacon.

Muller, Edward N. (1997), "Economic Determinants of Democracy", in Inequality, Democracy and Economic Development, Cambridge: Cambridge University Press.

Muller, Edward N. and Mitchell A. Seligson (1994), "Civic Culture and Democracy: The Question of the Causal Relationships", in American Political Science Review, no. 88, Texas: Department of Political Science, University of North Texas.

Nohlen, Dieter (1992), Elecciones y Sistemas de Partidos en América Latina, San José, Costa Rica: Instituto Interamericano de Derechos Humanos.

Nohlen, Dieter (2005), Elections in the Americas: A Data Handbook, vol. 2, Oxford: Oxford University Press.

Nohlen, Dieter (1993), Enciclopedia Electoral Latinoamericano y del Caribe, San José, Costa Rica: Instituto Interamericano de Derechos Humanos.

Norris, Pippa (1999), Critical Citizens: Global Support for Democratic Government, Oxford: Oxford University Press.

O’Donnell, Guillermo et al. (1986), Transitions from Authoritarian Rule, Baltimore: Johns Hopkins University Press.

Pateman, Carole (1970), Participation and Democratic Theory, New York: Cambridge University Press.

Peeler, John (1998), Building Democracy in Latin America, Boulder, co: Lynne Reinner Publishers.

Peeler, John (1992), "Elite Settlements and Democratic Consolidation in Latin America: Colombia, Costa Rica, and Venezuela”, in John Higley and Richard Gunter [eds.], 
Convergencia Revista de Ciencias Sociales, núm. 67, 2015, Universidad Autónoma del Estado de México

Elites and Democratic Consolidation in Latin America and Southern Europe, New York: Cambridge University Press.

Peeler, John (1985), Latin American Democracies: Colombia, Costa Rica, and Venezuela, Chapel Hill: University of North Carolina Press.

Perez, Orlando J. et al. (2010), “The Honduran Catharsis”, in Americas Quarterly, New York: Americas Society and Council of the Americas.

Perez, Orlando J. and Mitchell A. Seligson (2008), Political Culture of Democracy in Nicaragua: The Impact of Governance, Nashville, Tennessee: Latin American Public Opinion Project.

Przeworski, Adam (1986), "Some Problems in the Study of the Transition to Democracy", in Guillermo O'Donnell et al. [eds.], Transitions from Authoritarian Rule, Baltimore: Johns Hopkins University Press.

Przeworski, Adam et al. (2000), Democracy and Development: Political Institutions and WellBeing in the World, 1950-1990, Cambridge: Cambridge University Press.

Putnam, Robert D. (2000), Bowling Alone: The Collapse and Revival of American Community, New York: Simon \& Schuster.

Putnam, Robert D. (1993), Making Democracy Work: Civic Traditions in Modern Italy, Princeton, NJ: Princeton University Press.

Putnam, Robert D. (1995), “Tuning in, Tuning Out: The Strange Disappearance of Social Capital in America”, in PS: Political Science and Politics, vol. 28, no. 4, Cambridge: American Political Science Association, Cambridge University Press.

Robinson, William I. (1996), Promoting Polyarchy: Globalization, U.S. Intervention, and Hegemony, Cambridge: Cambridge University Press.

Robinson, William I. (2003), Transnational Conflicts: Central America, Social Change and Globalization, London: Verso.

Rose, Richard et al. (1998), Democracy and Its Alternatives: Understanding Post-Communist Societies, Oxford: Oxford University Press.

Rueschemeyer, Dietrich et al. (1992), Capitalist Development and Democracy, Cambridge: Cambridge University Press.

Rustow, Dankwart (1970), “Transitions to Democracy: Toward a Dynamic Model”, in Comparative Politics, vol. 2, no. April, New York: The City University of New York.

Schneider, Ronald M. (2007), Latin American Political History: Patterns and Personality, Boulder: Westview Press.

Seligson, Mitchell A. (1987), "Development, Democratization and Decay: Central America at the Crossroads", in James M. Malloy and Mitchell A. Seligson [eds.], Authoritarians and Democrats: The Politics of Regime Transition in Latin America, Pittsburgh: University of Pittsburgh Press.

Seligson, Mitchell A. (2002), “Trouble in Paradise: The Impact of the Erosion of System Support in Costa Rica, 1978-1999”, in Latin American Research Review, vol. 37, no. 1, Pittsburgh: University of Pittsburgh Press.

Seligson, Mitchell A. and John A. Booth (2010), "Crime, Hard Times and Discontent", in Journal of Democracy, vol. 21, no. 2, Baltimore: Johns Hopkins University Press. 
Seligson, Mitchell A. et al. (2006), Auditoría de la Democracia: Bolivia, 2006, Cochabamba: Latin American Public Opinion Project (LAPOP).

Smith, Peter H. (1974), Argentina and the Failure of Democracy: Conflict among Political Elites, Madison: University of Wisconsin Press.

Smith, Peter H. (2005), Democracy in Latin America: Political Change in Comparative Perspective, New York: Oxford University Press.

Stepan, Alfred (1986), "Paths toward Redemocratization: Theoretical and Comparative Considerations", in Guillermo O'Donnell et al. [eds.], Transitions from Authoritarian Rule, Baltimore: Johns Hopkins University Press.

Vanhanen, Tatu (1997), Prospects of Democracy: A Study of 172 Countries, London: Routledge.

Whitehead, Lawrence (1991), “The Imposition of Democracy”, in Abraham Lowenthal [eds.], Exporting Democracy: The United States and Latin America, Baltimore: Johns Hopkins University Press.

\section{Electronic resource}

Seligson, Mitchell A. and John A. Booth (2009), Special Report on Honduras: Predicting Coups? Democratic Vulnerabilities, the Americas barometer and the 2009 Honduran Crisis 2009 [cited. Available at http://sitemason.vanderbilt.edu/lapop/ AmericasBarometerInsightsSeries/2009/8/1/i0821-special-report-on-honduraspredicting-coups-democratic-vulnerabilities-the-americasbarometer-and-the-2009honduran-crisis-by-mitchell-a-seligson-and-john-a-booth- 


\section{Appendix 1}

\section{Figure 1}

\section{Possible relations between theories of democratization}

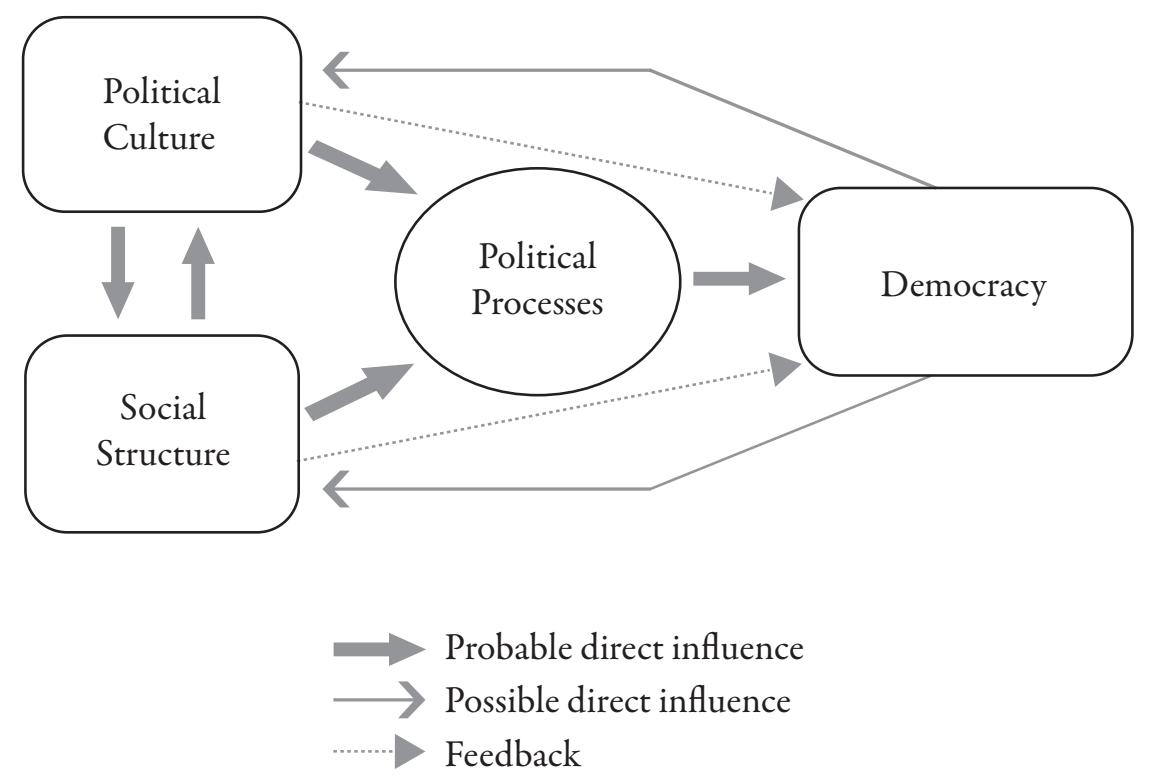

Source: Americas Barometer by LAPOP. 
John A. Booth and Leticia Heras-Gómez. Democracy in Latin America: status and prospects

Figure 2

Types of Government in the Americas, 1946-2008

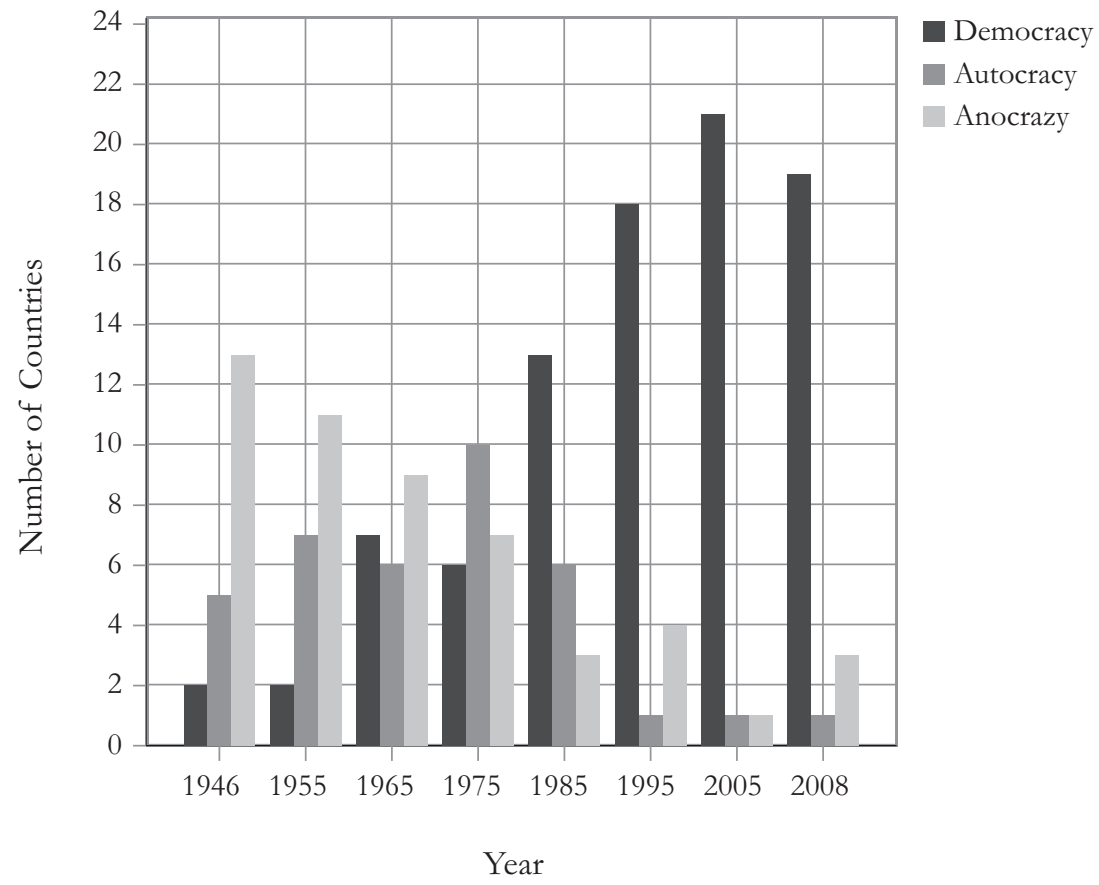

Source: Americas Barometer by LAPOP. 
Figure 3

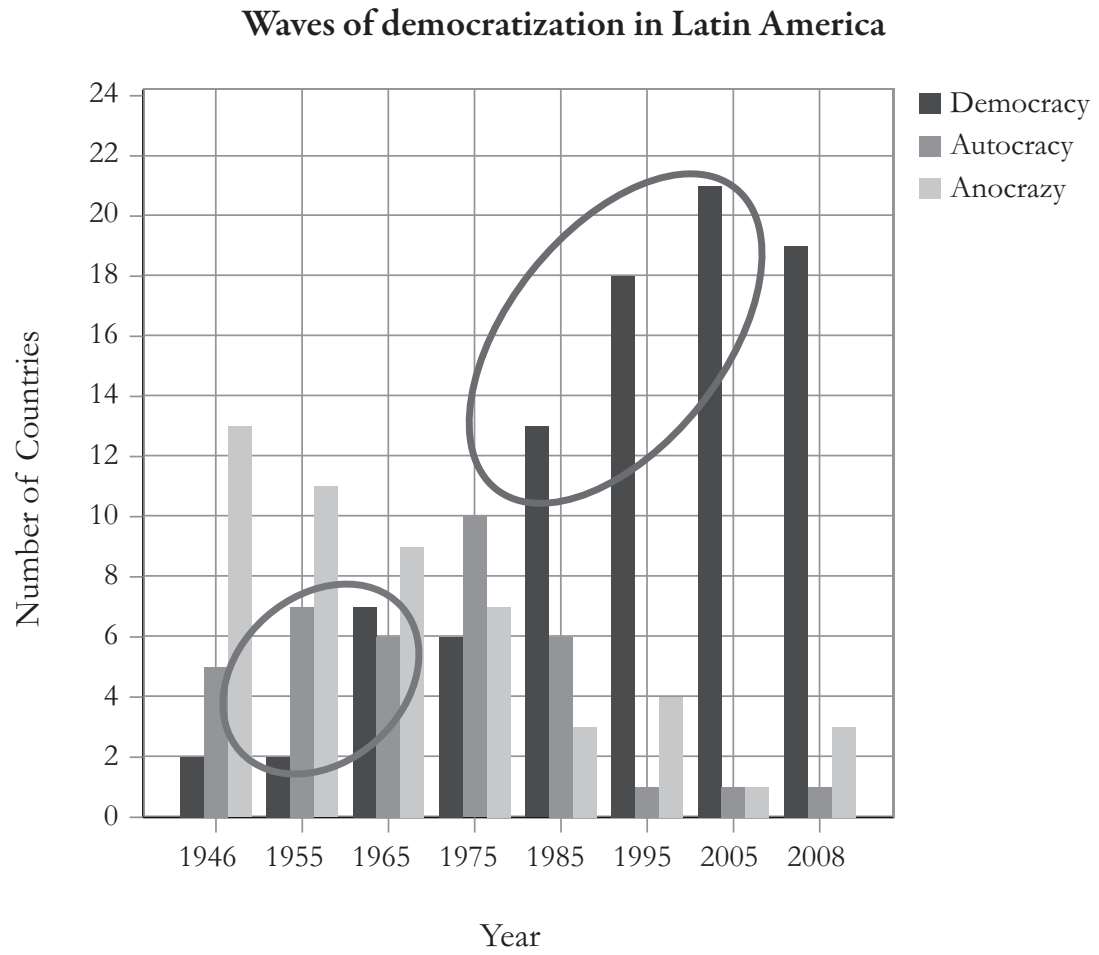

Source: Americas Barometer by LAPOP. 
John A. Booth and Leticia Heras-Gómez. Democracy in Latin America: status and prospects

Figure 4

\section{Percentage of citizens who prefer democracy 2008-2010 \\ (Black line $=50 \%)$}

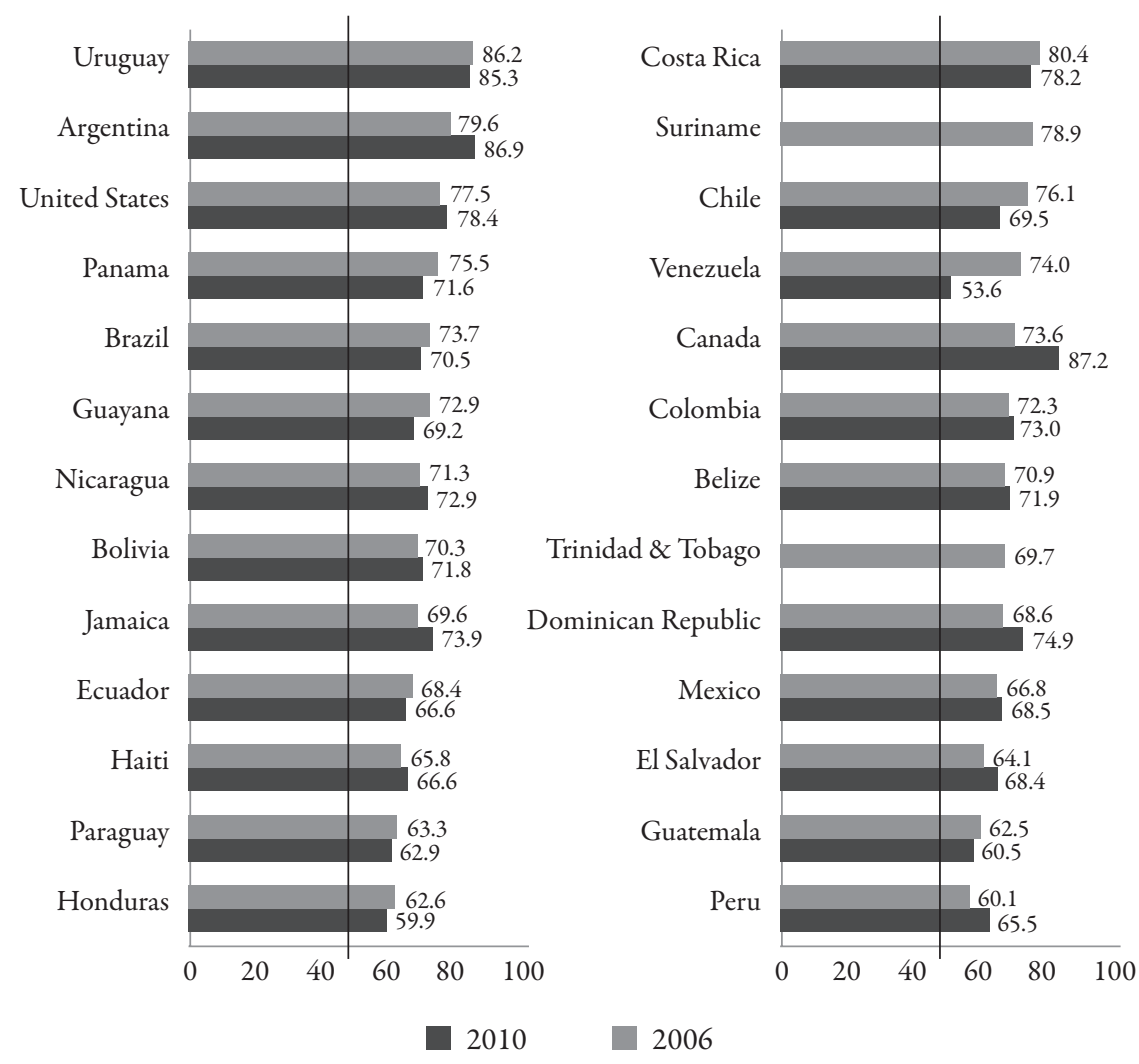

Support for Democracy

95\% Confidence Interval (Design-Effect Based)

Source: Americas Barometer by LAPOP. 
Figure 5

Percentage of citizens tolerant to the system critics, 2010 $($ Black line $=50 \%)$

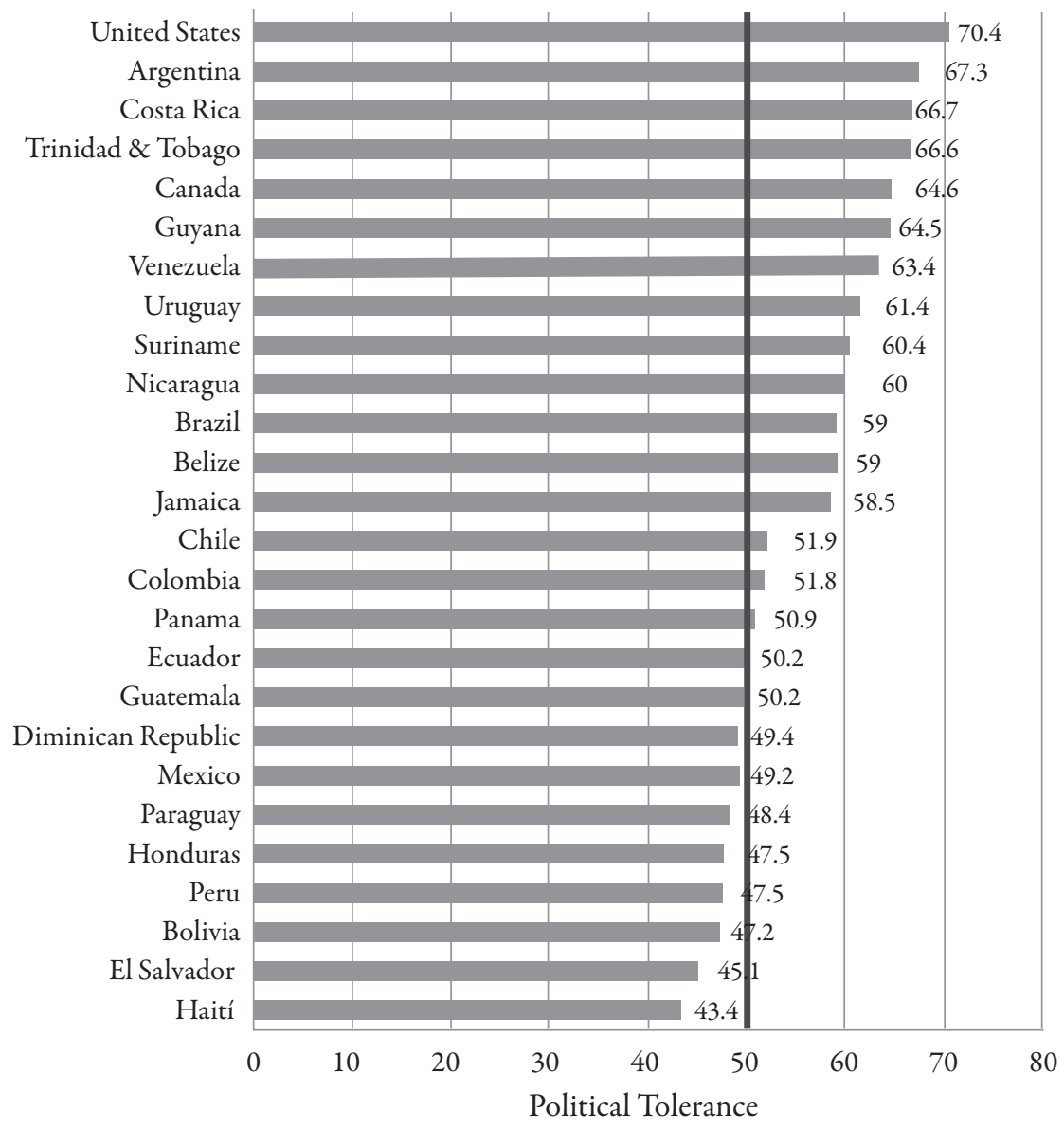

Source: Americas Barometer by LAPOP. 


\section{Figure 6}

\section{Percentage of citizens who support institutions (Black line $=50 \%)$}

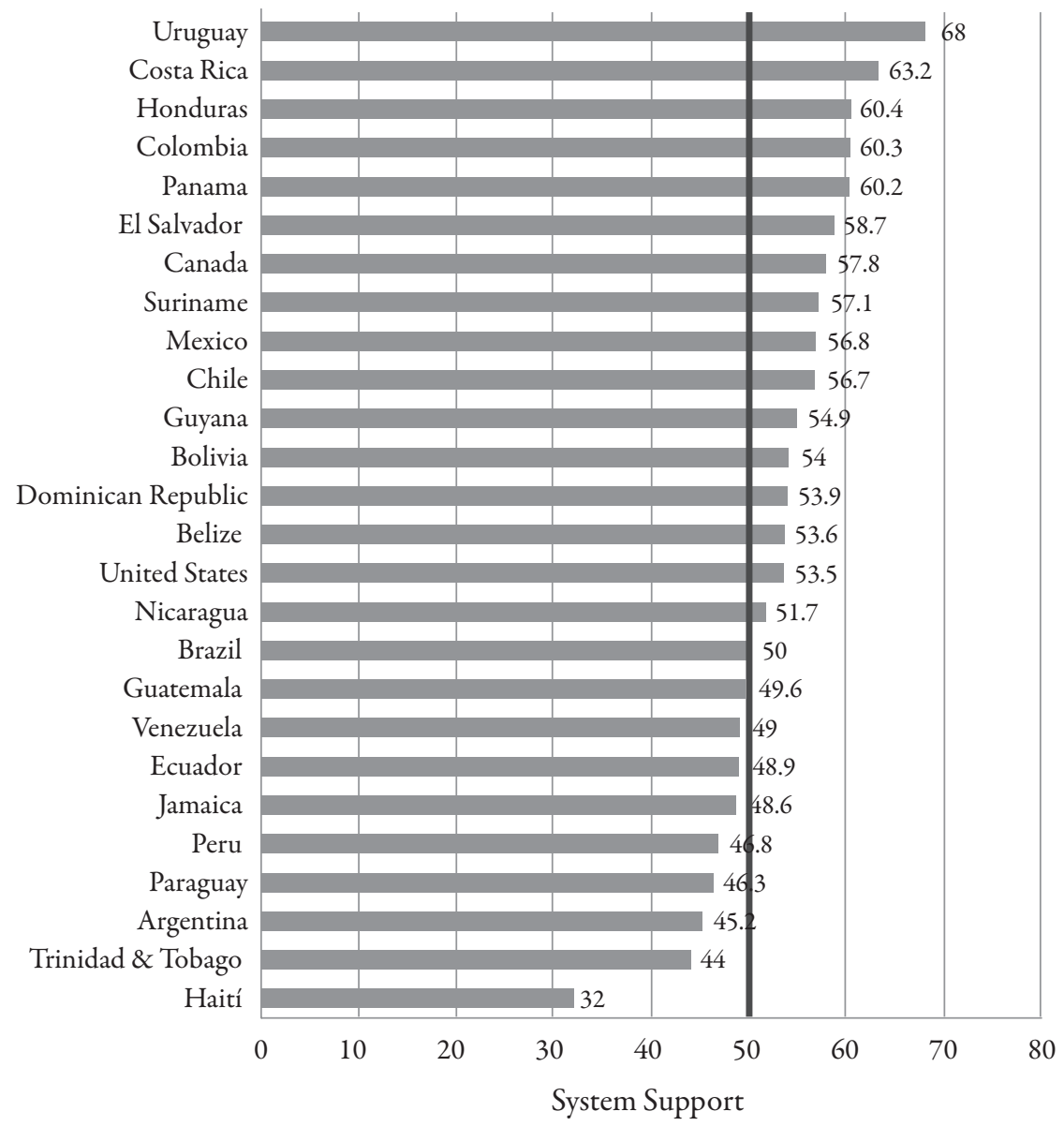

Source: Americas Barometer by LAPOP. 


\section{Figure 7}

\section{Percentage of citizens who support the rights of critics and institutions at a time}

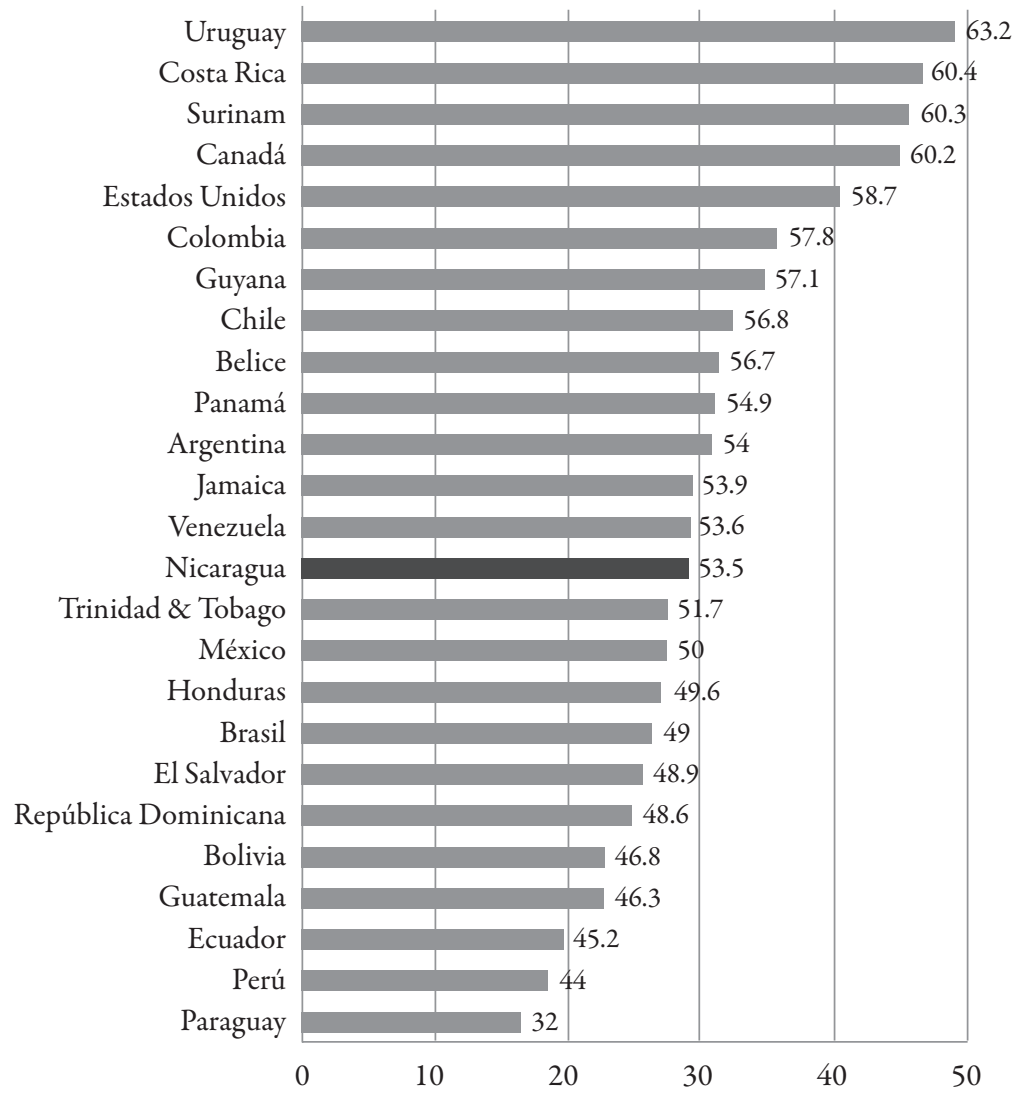

Source: Americas Barometer by LAPOP. 


\section{Figure 8}

\section{Levels of Triple Satisfaction, 2010 \\ $($ Black line $=50 \%)$}

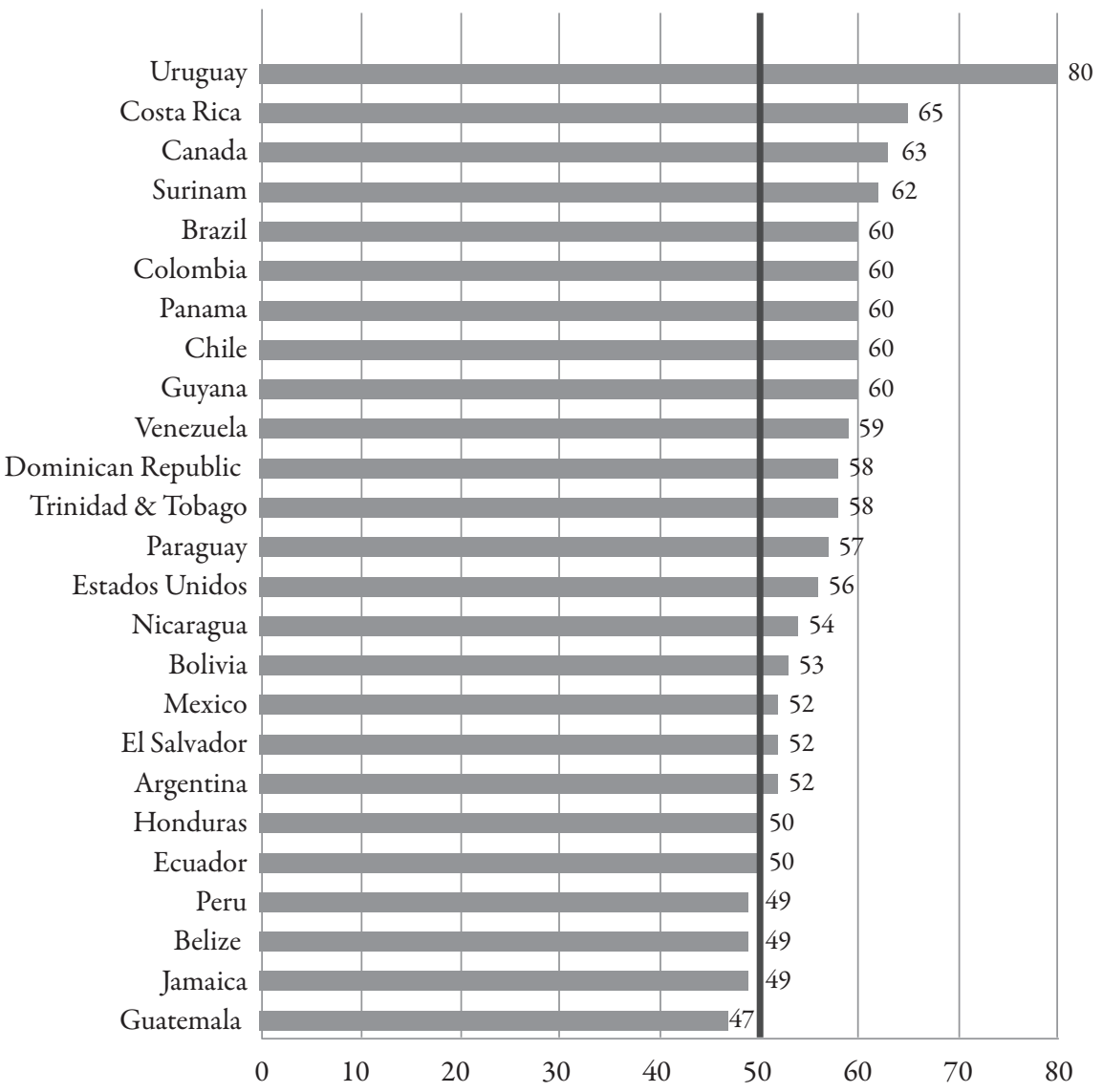

Source: Americas Barometer by LAPOP. 
Figure 9

\section{Setback for democracy?}

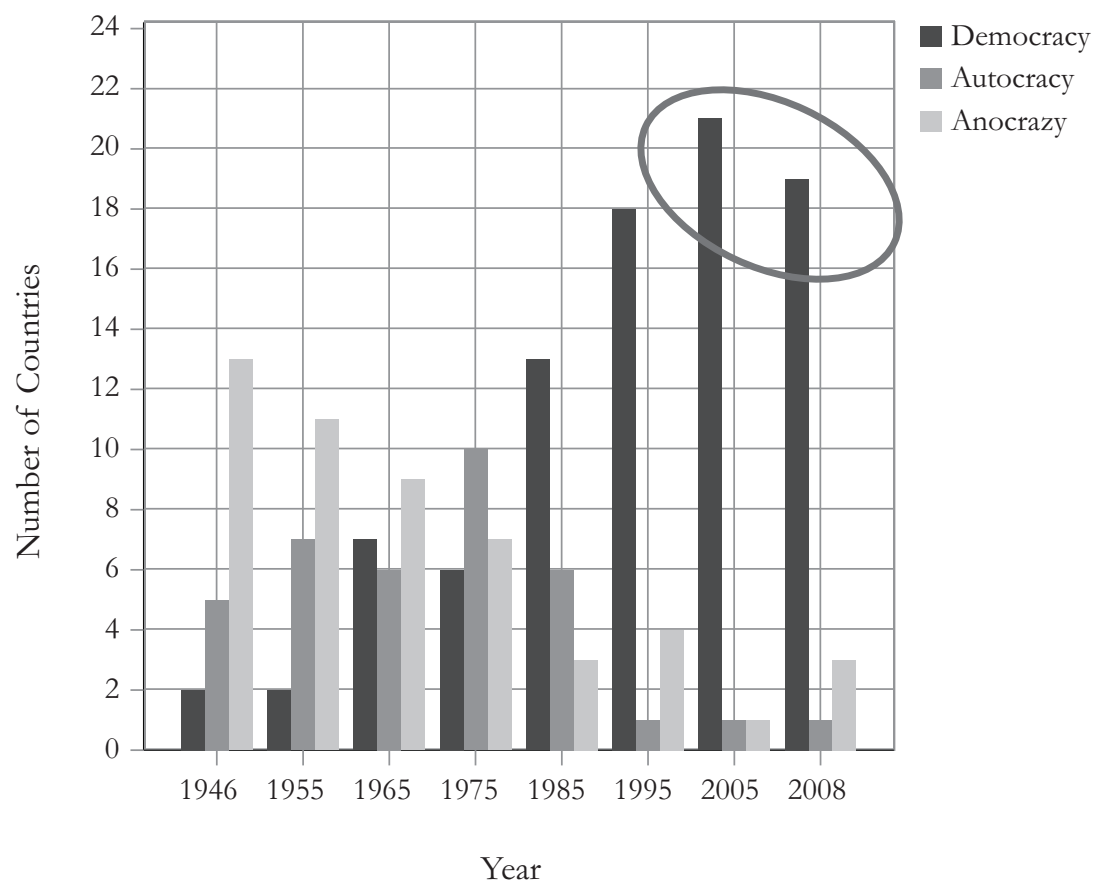

Source: Americas Barometer by LAPOP. 
John A. Booth and Leticia Heras-Gómez. Democracy in Latin America: status and prospects

\section{Figure 10}

\section{Levels of Triple Satisfaction with the system (0-100)}

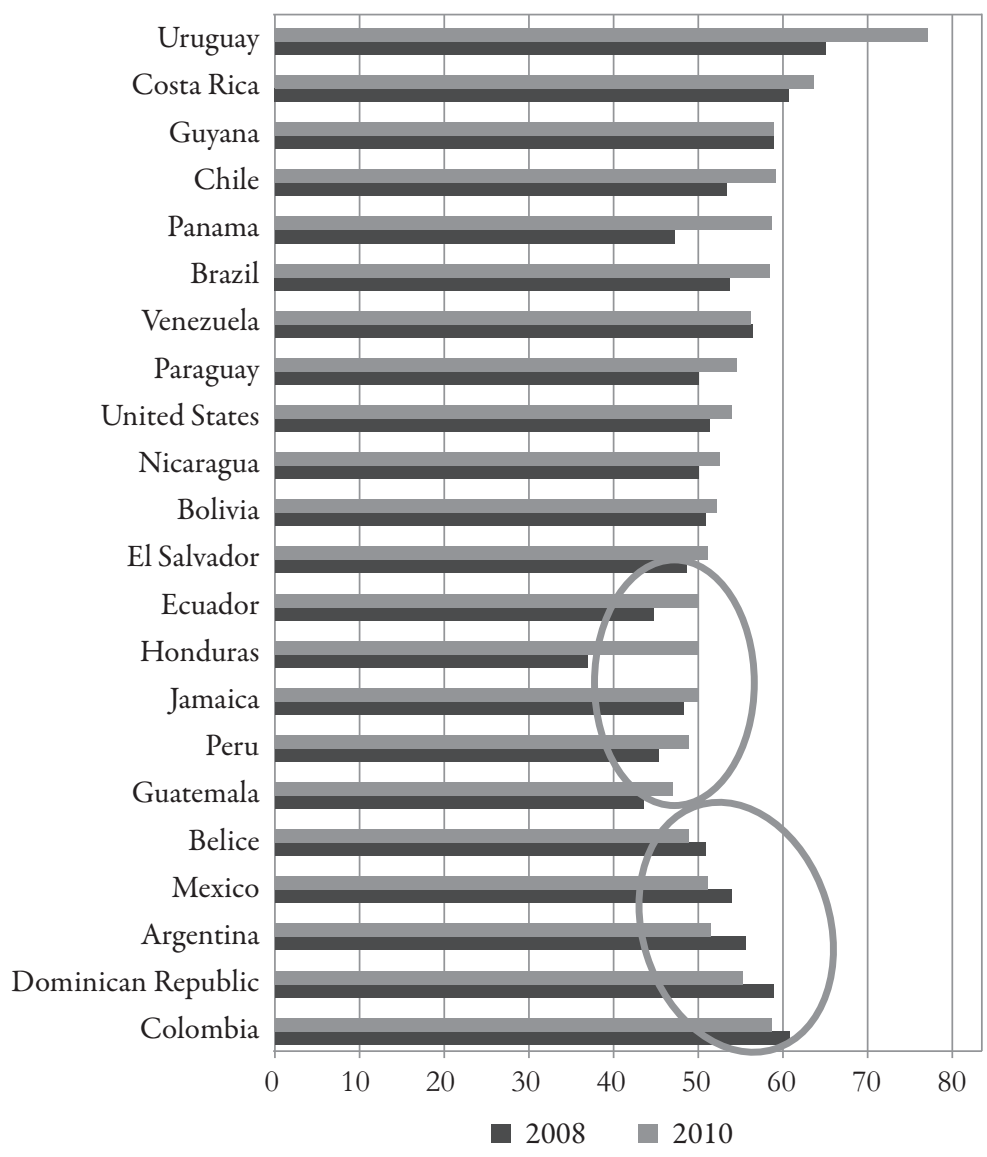

Source: Americas Barometer by LAPOP. 
Table 1

\begin{tabular}{lll}
\hline Institutional Problems & $\begin{array}{l}\text { Low levels of democratic } \\
\text { values }\end{array}$ & $\begin{array}{l}\text { Dynamics (erosion of } \\
\text { democratic values) }\end{array}$ \\
\hline Venezuela & Guatemala & Mexico \\
\hline Ecuador & Paraguay & Argentina \\
\hline Nicaragua & Jamaica & Belize \\
\hline Honduras & & \\
\hline
\end{tabular}

Source: Authors' own elaboration.

Leticia Heras Gómez is a researcher at the Faculty of Political Sciences in the Autonomous University of the State of Mexico. Her research topics are Political participation in Mexico and Latin America, Political Culture in Mexico and Latin America, and regional democratization. Her last publications are "Confidence in electoral institutions in Mexico: the IFE under the citizen regard", in the Revista Debates (Ufrgs, Brazil, vol. 5, 2011) and "An approach to political party membership: the case of emergent parties" in Convergencia, Revista de Ciencias Sociales (20, Mexico, no. 63, Sept-Dec, 2013).

John Booth is Regents Professor of Political Science at the University of North Texas. He is an acknowledge specialist of political culture and political participation in Latin America, as well as democratization and political violence in the area. He is author with Michell Seligson of The Legitimacy Puzzle in Latin America: Support and Democracy in eight nations (Cambridge University Press, 2009) and along with Thomas Walker and Christine Wade of Understanding Central America: Global Forces, Rebellion, and Change (Westview Press, 2006).

Reception: October 22nd, 2012.

Approval: June 20th, 2013. 